\title{
Lexicogrammar through colligation: Noun + Preposition in English and Norwegian
}

\author{
Hilde Hasselgård \\ University of Oslo (Norway)
}

This study compares sequences of noun and preposition in English and Norwegian using data from the English-Norwegian Parallel Corpus. One purpose is to test the use of sequences of part-of-speech tags as a search method for contrastive studies. The other is to investigate the functions and meanings of prepositional phrases in the position after a noun across the two languages. The comparison of original texts shows that the function of postmodifier is most frequent in both languages, with adverbial in second place. Other functions are rare. English has more postmodifiers and fewer adverbials than Norwegian. Furthermore, the prepositional phrases express locative meaning, in both functions, more frequently in Norwegian than in English. The study of translations reveals that the adverbials have congruent correspondences more often than postmodifiers, particularly in translations from English into Norwegian.

Keywords: prepositional phrase, colligation, postmodification, adverbial, English/Norwegian

\section{Introduction}

The contrastive study of lexicogrammar involves the challenge of identifying search strings that can retrieve the same type of construction(s) in both languages investigated. This challenge has most frequently been met by identifying a lexical correlate of particular constructions (Johansson, 2007: 37). This study uses a sequence of part-of-speech (PoS) tags as a window into cross-linguistic syntactic differences and similarities. The selected tag sequence is noun plus preposition, expected to retrieve nouns with a postmodifying prepositional phrase (PP) as well as chance sequences of a noun and a PP with adverbial function, as illustrated by (1) and (2) from the English-Norwegian Parallel Corpus (ENPC) on which this study is based. Both examples have congruent translations, suggesting structural similarity between English and Norwegian PPs. ${ }^{1}$

\footnotetext{
${ }^{1}$ Corpus examples are written as they occur in the corpus, with the source text first. Any abbreviations are marked with three dots. Identification tags ending in T (e.g. HW2T) indicate that the example is a translation. Norwegian examples are followed by a transliteration marked "Lit." to clarify the structure, except where the published translation is word-for-word equivalent.
} 
(1) Nor did he enjoy his meetings with Dr Forestier... (BC1)

Han likte heller ikke konsultasjonene hos doktor Forestier ... (BC1T)

Lit: "He liked either not the consultations at doctor Forestier"

(2) Og han hadde lagt klaerne på en stein mye lenger opp. (HW2)

Lit: "And he had laid the clothes on a rock much further up."

And he had laid his clothes on a rock much nearer the grove. (HW2T)

The noun in the sequence provides a grammatical context for the PP. In the case of postmodifying PPs it will typically be the head of a complex noun phrase, and it will be relevant to investigate the meaning relation between the head and the PP. PPs functioning as adverbials, however, are not part of the same syntagm as the preceding noun, so that the noun and the PP will be more peripherally related semantically too, if at all.

The following research questions are addressed:

- What are the syntactic functions of PPs following a noun in Norwegian and English?

- What meanings do the PPs convey?

- $\quad$ Are there quantitative and qualitative differences between the languages as regards the functions and meanings of postnominal PPs?

- To what extent are translations congruent?

The use of PoS tag sequences as a starting point has not been common in cross-linguistic corpus studies (though see Wilhelmsen, 2019 and monolingual studies of L1 and L2 performance, e.g. Granger and Rayson, 1998; Granger and Bestgen, 2014). Hasselgård (2016) searched for a combination of function words and wildcards ('the * of the *') as a colligational framework (Renouf and Sinclair, 1991) for a contrastive study of complex noun phrases. A major weakness of this search method was that it was impossible to identify an equivalent colligational framework for Norwegian, so that Norwegian was studied only through the English pattern (Hasselgård, 2016: 77). The search method used in the current study is one that should have equal potential in both languages and furthermore casts the net wider to include more prepositions. As shown in examples (1) and (2), it elicits not only complex noun phrases but also sequences with other functions. Hence, the tag sequence 'noun + preposition' should be able to illuminate cross-linguistic syntactic differences between English and Norwegian to do with both postmodification of nouns and clause-level adverbials. The proportional distribution of these functions may in turn indicate preferences towards a nominal or a clausal style.

English is expected to have more postmodifying PPs and Norwegian to have more adverbial PPs. This is based on the finding that postmodifying of-phrases frequently have noncongruent Norwegian correspondences (Hasselgård 2016). Furthermore, the claim that English is more nominal while Norwegian is more verbal/sentential (e.g. Nordrum, 2007; Behrens, 2014), might promote postmodifying PPs in English and clause-level adverbials in Norwegian.

The remainder of the paper is organized as follows: Section 2 summarizes some previous studies of prepositional phrases in English and Norwegian. The material and method of the study are outlined in Section 3. Section 4 presents the classificatory framework before the investigation itself appears in Section 5. Section 6 offers a summary of the findings and some concluding remarks. 


\section{Prepositional phrases in English and Norwegian}

Prepositional phrases are structurally similar in English and Norwegian, except that Norwegian prepositions can be complemented by the equivalents of to-infinitives and that-clauses ( $\stackrel{a}{a}$ infinitives, at-clauses) (Holmes and Enger, 2018: 323). In both languages, prepositions can be stranded after their complement, and occasionally, a preposition is postposed, as in the case of English ago (e.g. three weeks ago). ${ }^{2}$

In both English and Norwegian, prepositional phrases are common realizations of adverbials and noun postmodifiers (Biber et al., 1999: 104; Holmes and Enger, 2018: 401). ${ }^{3}$ According to Biber et al., PPs are "by far the most common type of postmodification in all registers" (1999: 607) and furthermore the most frequent realization of adverbials, particularly of the circumstantial type (1999: 768; see also Hasselgård, 2010: 38). Similarly, Elsness (2014: 95) shows that prepositions are the most frequent part of speech to follow the tag sequence 'determiner + noun'.

Prepositional phrases also have other syntactic functions. Fang (2000) lists nine in a study of English PPs based on the ICE-GB corpus. ${ }^{4}$ Adverbial and NP postmodifier are by far the most frequent ones, accounting for close to $90 \%$ of the PPs, but PPs also function as postmodifier of adjectives and adverbs, subject and object complements, complement of preposition, focus of $i t$-cleft and stand-alone phrase (Fang, 2000: 188). A similar list of the functions of Norwegian PPs is found in Faarlund et al. (1997: 411).

While the 'noun + PP' sequence may superficially resemble a pattern (in the sense of Hunston and Francis, 2000), it is in fact not. More precisely, there may be instances of patterns among the sequences extracted from the corpus, where the preposition is selected by the noun and the PP can be seen as a complementation of the noun (Hunston and Francis, 2000: 40). Such patterns are written either as $\mathbf{N}$ prep or with a specific preposition such as $\mathbf{N}$ of $\mathbf{n}$ (ibid.: 57). If the preposition is not constrained by the preceding noun, there is no pattern even if the 'noun + prep' sequence may be frequent. As Hunston and Francis point out: "frequent cooccurrences of words do not necessarily indicate the presence of a pattern" (2000: 71).

Contrastive studies of the syntactic functions of PPs indicate that languages may have different restrictions and preferences regarding their use even when the linguistic resources are similar. For example, Mott (2013) finds that postmodifying PPs are more restricted in Spanish than in English, particularly in locative expressions (2013: 168), which he links to differences in lexicalization and grammaticalization. Similarly, Moreira-Rodríguez (2006) finds English postmodifying PPs more flexible than Castilian Spanish ones, which may cause Englishspeaking learners of Spanish to overuse PP modifiers at the cost of relative clauses.

There are not many contrastive studies of PPs in English and Norwegian. In a series of studies, Thomas Egan (e.g. Egan, 2013) discusses the semantics and cross-linguistic correspondences of a number of prepositions, but focuses less on their syntactic functions. As noted above, Hasselgård (2016) compares the English pattern 'the N1 of the N2' to its Norwegian correspondences, noting a high degree of divergence, particularly due to the fact that Norwegian lacks a preposition equivalent to of, whose main role is to "[combine] with preceding nouns to produce elaborations of the nominal group" (Sinclair, 1991: 83). Thus, a number of 'the $\mathrm{N} 1$ of the $\mathrm{N} 2$ ' sequences correspond to compound nouns, $s$-genitives and expressions involving adverbs (Hasselgård, 2016: 65; see also Holmes and Enger, 2018: 355).

\footnotetext{
${ }^{2}$ For arguments for the analysis of ago as a preposition, see Huddleston and Pullum (2002: 632).

${ }^{3}$ Holmes and Enger (2018) do not present frequency data, but the functions of postmodifier and adverbial are mentioned first under the functions of PPs, possibly indicating an order of importance.

${ }^{4}$ The main objective of Fang (2000) is to test a lexical model for the automatic assignment of syntactic function.
} 
Furthermore, in a study of clausal postmodification of nouns in English and Norwegian, Elsness (2014: 91) argues that "there are some notable differences in the structure of the noun phrase between the two languages", particularly in the use of modifiers. His results suggest that Norwegian prefers more "explicit" noun modification than English, for example favouring finite postmodifying clauses over phrasal postmodifiers, which are considered a more "compact" type of modification (see also Biber and Gray, 2016: 232). Behrens (2014: 157) observes a greater preference for nominalizations in English than in Norwegian academic prose with a correspondingly higher number of actions and events coded as clauses in Norwegian. This will have consequences for the function of associated PPs, which will be postmodifiers in the case of nominalizations and adverbials in the case of clausal expressions.

While the above-mentioned studies have identified some cross-linguistic differences regarding PPs as postmodifiers, there is less reason to expect the same kind of differences in the realization of adverbials. For example, Hasselgård (2021: 211) finds that similar proportions of time adverbials in English and Norwegian news discourse are realized by prepositional phrases. A contrastive analysis of adjunct adverbials in clause-initial position in fiction points in the same direction (Hasselgård, 2014: 85). Previous studies thus suggest that the greatest cross-linguistic differences will be found with PPs functioning as postmodifiers of nouns. Furthermore, it is expected that the languages will differ as to the relative frequencies of what is believed to be the main functions of PPs, namely postmodifiers and adverbials.

\section{Material and method}

The material for this study comes from the fiction part of the English Norwegian Parallel Corpus (ENPC fiction), which was accessed through the Glossa interface (Johannessen et al., 2008). The ENPC is a bidirectional parallel corpus in which originals and translations are aligned at sentence level (Johansson, 2007: 11, 14). The fiction part consists of 30 original text extracts (totalling just above 400,000 words) in either language with translations into the other. ${ }^{5}$ In the Glossa version, all original and translated texts are fully PoS-tagged. ${ }^{6}$

The search string entered in the 'Extended search' form in Glossa was 'noun' followed by 'preposition' with no elements allowed in between. This string does not give full recall of postmodifying PPs, since postmodifiers need not follow their head noun directly. In the case of adverbial PPs, the recall is even lower, since adverbial PPs are by no means restricted to postnominal position. However, the postnominal position is one where both functions can be found in PPs, which counts greatly in its favour, considering that the study of alternation is a major concern of this paper. Thus, bearing in mind that the position immediately after a noun is likely to enhance the number of PPs functioning as postmodifiers, the tag sequence "noun + preposition' was preferred to searches for prepositions only.

The searches were made only in original English and Norwegian texts, but the aligned translations were also retrieved in order to perform the study of translations presented in Section 5.6. The corpus searches returned 17,146 'noun + preposition' sequences in Norwegian and 17,830 in English, corresponding to 4,249 and 4,430 per 100,000 words, respectively. Due to the need for manual analysis of the functions, meanings and correspondences of the prepositional phrases, it was necessary to reduce the material to random samples. The sample size was set to 500 concordance lines per language.

Each concordance line in the random samples was scrutinized to make sure it actually represented a sequence of noun and preposition. This manual sifting revealed some tagging

\footnotetext{
${ }^{5}$ See https://www.hf.uio.no/ilos/english/services/knowledge-resources/omc/sub-corpora/.

${ }^{6}$ The English texts were tagged with the TreeTagger (www.cis.uni-muenchen.de/ schmid/tools/TreeTagger/) and the Norwegian texts with the Oslo Bergen Tagger (Johannessen et al., 2012).
} 
errors. Concordance lines were excluded if the noun tag was wrong (as in example (3), where gossip is a verb) or if the preposition tag was wrongly assigned, as in (4), where the highlighted word is a relative pronoun - a type of word which is never, to my knowledge, classified as a preposition.

(3) He said, "I do n’t gossip with Harold, Ginny." (JSM1)

(4) She was aware of the impact that this declaration made. (AB1)

Some cases are problematic due to "lack of consensus about annotation schemes" (Leech 2011: 168). The highlighted words in examples (5) and (6) are traditionally classified as subordinator and adverb/particle, respectively (e.g. Biber et al., 1999: 76). However, they are regarded as prepositions in a number of other frameworks, such as Huddleston and Pullum's (2002: 599, 612). As a consequence of this expansion of the category, prepositions can be complemented by finite clauses and they can be intransitive, i.e. occur without a complement. A similar analysis of Norwegian is found in Holmes and Enger (2018: 322) and in Faarlund et al. (1997), which is the basis for the PoS classification in the Oslo-Bergen tagger (Johannessen et al., 2012: 57). Allowing for this analysis, examples such as (5) and (6) were retained in the material. Finally, example (7) shows a case of a stranded preposition occurring at a distance from its complement. Such examples were also retained.

(5) Mattie didn't think about the heat as she walked beside Butch. (GN1)

(6) ... but mostly to re-create that moment when Townsend brought Celia in... (AH1)

(7) Han forsøkte å dempe smertene litt ved hjelp av kamferdråper som han masserte både jekselen og tannkjøttet med. (EG2)

Lit: "...which he massaged both the molar and the gums with"

He tried to alleviate the pain with camphor drops, which he rubbed into the offending molar and inflamed gum with the tip of his finger. (EG2T)

It may be argued that the PoS-tags in the corpus are to some extent inconsistent - though not necessarily wrong - as those subordinating conjunctions/adverbs that are homonyms of traditional prepositions seem more likely to be tagged as preposition than others - there are for example no instances of because/fordi in the samples retrieved. Fortunately, the English and the Norwegian taggers appear to behave relatively similarly in this respect (see Section 5.2). On balance, this potential inconsistency was considered acceptable in view of issues of replicability. The resulting material thus retains the PoS classification assigned by the taggers with only the obvious tagging errors removed (see Table 1 in Section 5.1 for the final size of the dataset).

\section{Classificatory framework}

Each instance of a 'noun + preposition' sequence was annotated for the syntactic function of the postnominal PP, the complement of the preposition and the general meaning of the PP. The categories are described below.

The classification of syntactic functions is in agreement with categories found in e.g. Biber et al. (1999). The following functions were identified: postmodifier (of preceding noun), adverbial (independent of preceding noun), modifier of prenominal adjective, as in (8), part of complex prepositions, e.g. in front of, ved siden av ('at the side of' = 'beside'), and part of multi-word verb, as in (9).

(8) ... to move to Amsterdam, a larger city than Leiden... (JH1)

... å flytte til Amsterdam, en større by enn Leiden... (JH1T) 
(9) Men alle hadde naturligvis lagt merke til det. (EG1)

Lit: "But everyone had naturally laid mark to ['noticed'] it."

... no one could have failed to notice such outlandish habits ... (EG1T)

The meanings of adverbials are identified according to the categories of adjuncts outlined in Hasselgård (2010: 39), while conjuncts and disjuncts are not specified in further detail because of their low numbers. The adjuncts that occur more than once or twice are of the following types:

- Manner (including accompaniment and method/means), e.g. ...they raised their voices

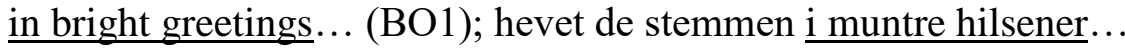

- Participant, e.g. Han ... hentet varene til henne. (HW1); He... got the groceries for her.

- $\quad$ Place, e.g. En gang i uken har hun time på helsesenteret... (BV2); Once a week she has a session at the health centre,,..

- $\quad$ Reason/purpose, e.g. Sarah would be stopping by the house for the rug. (AT1); Sarah ville komme til huset for å hente teppet.

- $\quad$ Respect, e.g. to tell his wife about the journey up the M1. (ST1); ...og fortelle kona om turen han hadde fått.

- $\quad$ Time, e.g. We were living with my mother for four years, ... (DL2); Vi bodde hos mor i fire år ...

The general meanings of postmodifying PPs were identified according to the framework detailed in Hasselgård (2016, 2019), based on Sinclair (1991), although it had to be modified because of the wider scope of the present investigation, i.e. the greater variety of prepositions studied. The meaning categories are an attempt to describe the relationship between the noun preceding the preposition (N1) and the head of the NP complementing the preposition (N2). Those that recur in the material are the following: ${ }^{7}$

- Argument of nominalization: The noun is a nominalization and the PP represents an argument (subject, object, adjunct), as in the presence of death; narvar av døden (nom$\mathrm{S})$, the lending of money; utlån av penger (nom-O), undringen over livet; their astonishment at the world (nom-A). This category was used whenever the noun was a nominalization, regardless of meaning.

- Attribute: The PP specifies a property of the NP head, e.g. mannen med de store hendene; the man with the large hands.

- $\quad$ Focus: The first noun specifies some aspect of the second (Sinclair, 1991: 87), e.g. et glass med syltet $\phi y ;$ a jar of jam.

- Locative: The PP has locative meaning, e.g. køen ved disken; the queue at the counter

\footnotetext{
7 The examples all come from the material studied. In order to illustrate both languages simultaneously, only examples with congruent translations have been selected here.
} 
- $\quad$ Part: a part-whole relationship between N1 and N2, e.g. the foot of a tree; foten av et tre.

- Possessive: the noun in the PP denotes the possessor of the preceding referent, e.g. minen til et menneske som ...; the expression of someone who...

- Quantifier: The first noun quantifies the second, e.g. tusener av skritt; thousands of footsteps.

- Support: The noun in the PP carries the most important meaning and is the notional head of the NP, while the preceding noun has a supporting role (Sinclair, 1991: 89), e.g. various forms of self-advertisment; forskjellige former for egenreklame.

- Temporal: the PP has temporal meaning, e.g. lovtraer om sommeren; green trees in summertime.

For the study of translations (Section 5.6), the correspondences were classified according to the framework presented in Johansson (2007: 25) as congruent (having the same formal structure as the source), non-congruent (having a different formal structure than the source), and zero (in cases where the 'noun + preposition' sequence had no correspondence in the translation). See Section 5.6 for further explanation and examples.

\section{Corpus analysis}

This section presents the analysis of the two random samples of 'noun + preposition'. After a general overview of the data, the English and Norwegian prepositions and the types of complementation are surveyed. Then follows an analysis of the syntactic functions of the postnominal PPs before the meanings of postmodifying and adverbial PPs are compared across the two languages. Section 5.6 looks into the translation correspondences of postmodifying and adverbial PPs in both directions of translation (English-Norwegian and Norwegian-English).

\subsection{Overview of the data}

As detailed in Section 3, random samples of 500 concordance lines were extracted from English and Norwegian original fiction texts. After the exclusion of wrongly tagged hits, the samples were reduced to 474 in English and 475 in Norwegian. For some reason, the random samples come from only 16 out of 30 corpus texts in either language, hence the samples may not be representative of the entire corpus. The overview is laid out in Table 1.

Table 1. Overview of retrieved instances of 'noun + preposition' in ENPC fiction.

\begin{tabular}{|l|r|r|}
\hline & English original & Norwegian original \\
\hline Total number of hits & 17,830 & 17,146 \\
\hline Random sample & 500 & 500 \\
\hline Excluded due to tagging error & 26 & 25 \\
\hline Adjusted sample & 474 & 475 \\
\hline Number of texts (of 30) & 16 & 16 \\
\hline
\end{tabular}




\subsection{The structure of PPs in English and Norwegian}

The prepositions occurring after nouns are more varied in Norwegian than in English, with 60 types in the Norwegian (adjusted) sample as against 46 in English. As shown in Table 2, the preposition of is vastly more frequent than any other preposition in the material, which is due to its "overwhelming pattern of usage being in nominal groups" (Sinclair, 1991: 83). Norwegian does not have any preposition with the same status and versatility in nominal groups (Hasselgård, 2016); hence the frequency of the first item on the Norwegian top 10 list is not very much greater than that of the second, and the frequencies drop much less steeply than in the case of English. Notably, the top item on the Norwegian list is a close correspondence of the second on the English list; in fact, with the exception of of, the two lists of prepositions are not very different.

Table 2. The most frequent prepositions in the samples.

\begin{tabular}{|l|l|r|l|r|}
\hline & \multicolumn{3}{|l|}{ English } & Norwegian \\
\hline 1 & of & 207 & $i$ ('in') & 80 \\
\hline 2 & in & 58 & på ('on', 'at') & 71 \\
\hline 3 & for & 34 & av ('of', 'off', 'by') & 58 \\
\hline 4 & with & 28 & med ('with') & 48 \\
\hline 5 & on & 23 & til ('to') & 48 \\
\hline 6 & from & 16 & for ('for') & 27 \\
\hline 7 & at & 14 & fra ('from') & 22 \\
\hline 8 & as & 9 & om ('about', 'if') & 11 \\
\hline 9 & about & 9 & etter ('after') & 9 \\
\hline 10 & by & 9 & over ('over', 'above') & 7 \\
\hline & & 407 & & 381 \\
\hline
\end{tabular}

The ten most frequent prepositions account for $85.9 \%$ of the English sample and $80.2 \%$ of the Norwegian sample. Of the remaining preposition types, the following occur more than twice (in order of decreasing frequency): English into, across, without, before, beside, since, than; Norwegian under, ved ('by'), der ('there'), rundt ('around'), hos ('at'), mellom ('between'), opp ('up'), som ('as'), foran ('in front of'), inne i ('inside'), mot ('against'), uten ('without').

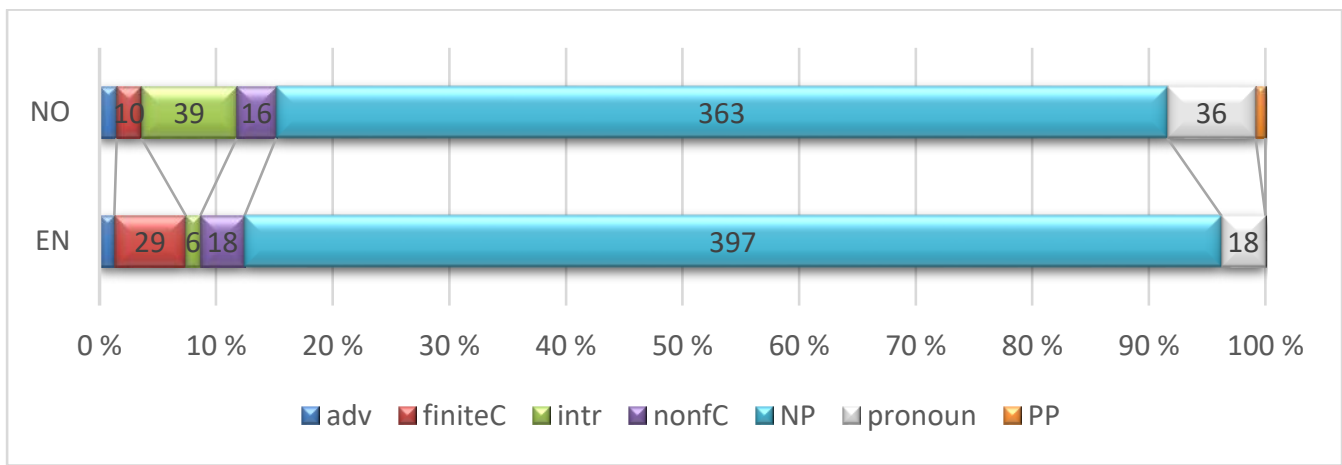

Figure 1. The complementation of the prepositions in Norwegian and English.

Figure 1 shows the distribution of PP complements in the material. Both languages show great preference for noun phrases as complements of the preposition, whether noun-headed (NP) or pronoun-headed (pronoun): $87.5 \%$ of the English PPs have a noun phrase as complement and $84 \%$ of the Norwegian ones. Intransitive prepositions, as in example (6) above, seem to be more frequent in Norwegian than in English, although this difference is conceivably due to the fact that the languages were tagged with different taggers. Finite clauses are - perhaps surprisingly - more frequent in English, but this is entirely due to instances of the traditional 
category of conjunction, as in (10), whose translation replicates the structure of its source. By contrast, some of the Norwegian finite clauses are at-clauses (i.e. that-clauses), as shown in (11). It should also be noted that the category of non-finite clauses consists exclusively of $\stackrel{a}{a}$ infinitives in Norwegian, ${ }^{8}$ and mostly of -ing participles in English.

(10) I listened to her groans of agony till we stopped at the edge of a river... (BO1) Jeg hørte henne stønne av smerte til vi stoppet på bredden av en elv... (BO1T)

(11) Det kunne gå uker og måneder uten at hun hørte noen nevne det. (HW1) Lit: "It could go weeks and months without that she heard anybody mention it" Weeks, sometimes months, could pass without her hearing anybody say those words. (HW1T)

\subsection{The syntactic functions of the PPs}

The analysis of the samples produced five different syntactic functions of the postnominal prepositional phrases. These were adverbial, postmodifier of noun, postmodifier of prenominal adjective, part of complex preposition, and part of multiword verb. Those functions that appear in Fang's (2000: 188) list but not in the present study are unlikely to occur directly after a noun, e.g. subject complement. The syntactic functions occur with highly unequal frequencies, as shown in Figure 2, where the functions of adjective modifier, complex preposition and multiword verb have been conflated in the category 'other'.

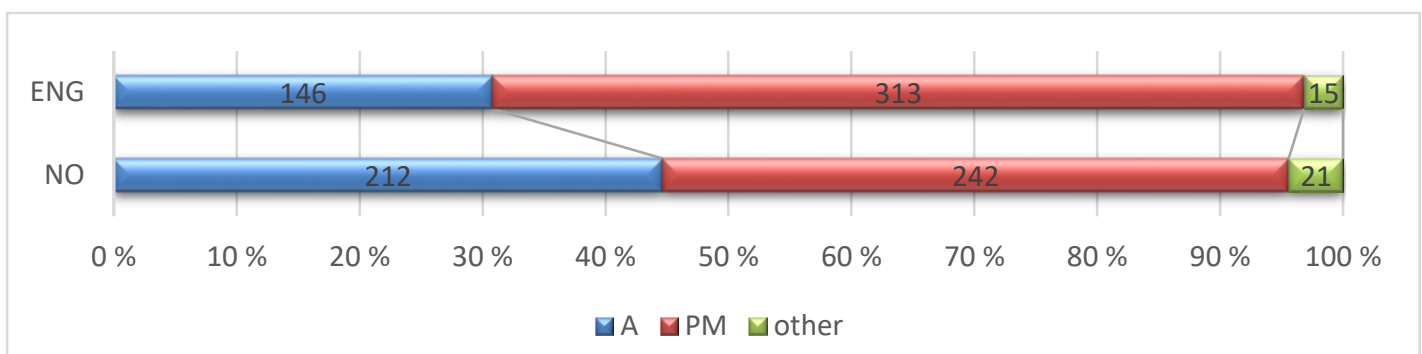

Figure 2. The syntactic functions of postnominal PPs in English and Norwegian (random samples excluding errors).

As the figure shows, the most frequent function of postnominal PPs in both languages is postmodifier (PM). This was expected, as the postnominal position is a favourable context for the postmodifying function. However, the postmodifiers are in even greater majority in English than in Norwegian, where adverbials (A) are rather more frequent. The difference in distribution between the languages is significant at $\mathrm{p}<0.001$ (Pearson's chi-squared test: 22.25, $\mathrm{DF}=2) .{ }^{9}$ Because of the very low frequencies of the 'other' categories, the remainder of this paper will focus on postmodifiers and adverbials.

\subsection{The meanings expressed by adverbial PPs}

Postnominal PPs functioning as adverbials are not part of the same syntagm as the preceding noun, so the meaning categories do not include any relation between the noun and the PP in the sequence. As detailed in Section 4, the classification follows Hasselgård (2010). Only those meanings that occur three times or more in one of the corpora are mentioned separately in

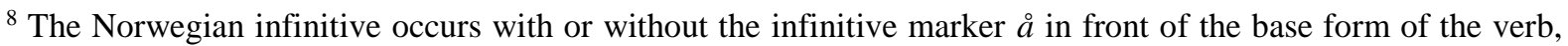
and is thus structurally similar to the English infinitive (Holmes and Enger, 2018: 226).

${ }^{9}$ The test was carried out using the tools available at http://corpora.lancs.ac.uk/stats/toolbox.php (Brezina, 2018).
} 
Figure 3. The 'other' category includes adjuncts of condition, concession, accompanying circumstance, and comparison. It is important to note that the distribution of adverbial categories shown in Figure 3 applies only in this particular grammatical context, not generally. For the general distribution of adverbials in English fiction, not limited to postnominal position or to prepositional phrases, see Hasselgård (2010: 260-262).

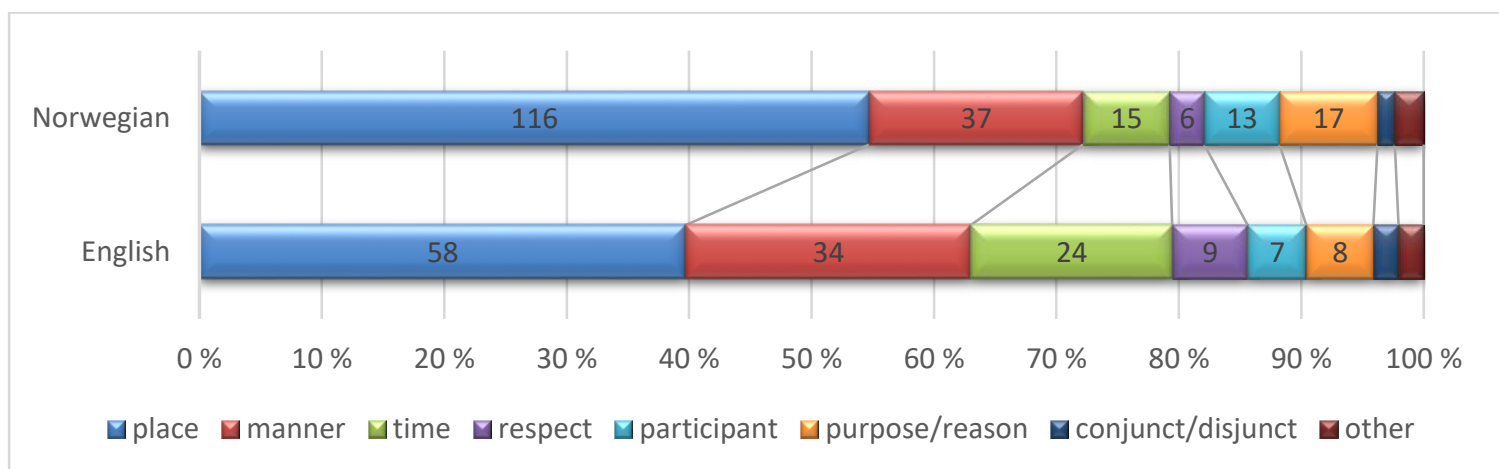

Figure 3. The meanings expressed by postnominal PPs functioning as adverbials in English $(\mathrm{N}=146)$ and Norwegian $(\mathrm{N}=212)$.

As Figure 3 shows, place adjuncts are the most frequent category in both languages, followed by manner. However, Norwegian has a greater proportion of place adverbials than English does (55\% vs. $39 \%)$. An example is given in (12).

(12) ...det var $95 \%$ vann $i$ en agurk... (JG1)

Lit: "there was $95 \%$ water in a cucumber"

.... cucumber was 95 percent water... (JG1T)

In contrast, English has greater proportions of manner adverbials (24\% vs $17 \%$ ) and time adverbials (16\% vs 7\%). ${ }^{10}$ Examples are given in (13) and (14).

(13) ... and stumbled out of the house in drunken merriment. (BO1)

...og sjanglet fulle og lystige ut. (BO1T)

Lit: "and stumbled drunk and merry out"

(14) We've been living in this motel for weeks... (MA1)

Vi har bodd på dette motellet $i$ mange uker... (MA1T)

Lit: "We have lived on this motel in many weeks..."

Other categories of adverbials are rather infrequent in both languages, and have more similar proportions.

\subsection{The meanings expressed by postmodifying PPs}

The meanings expressed by postmodifying PPs are analysed in relation to the preceding noun (see Section 4) and are displayed in Figure 4. While most of the meanings occur with rather similar frequencies in the two languages, a conspicuous difference is the far greater frequency of modifiers with locative meaning in Norwegian, where they account for $37 \%$ of the total compared to $18 \%$ in English. This is parallel to the situation with adverbial PPs, where spatial adjuncts are more frequent in Norwegian. An example of a locative postmodifier is given in (15), in which the translation mirrors the original.

\footnotetext{
${ }^{10}$ Time adjuncts are considerably less frequent in postnominal position than would be expected from their general frequency (Hasselgård, 2010: 261), which is due to the colligational restriction on the present dataset: many time adjuncts occur clause-initially or post-verbally (2010: 57).
} 
(15) Hun vinker bak gardinene $i$ annen etasje. (BV1)

Lit: "She waves behind the curtains in second floor."

She waves from behind the curtains on the first floor. (BV1T)

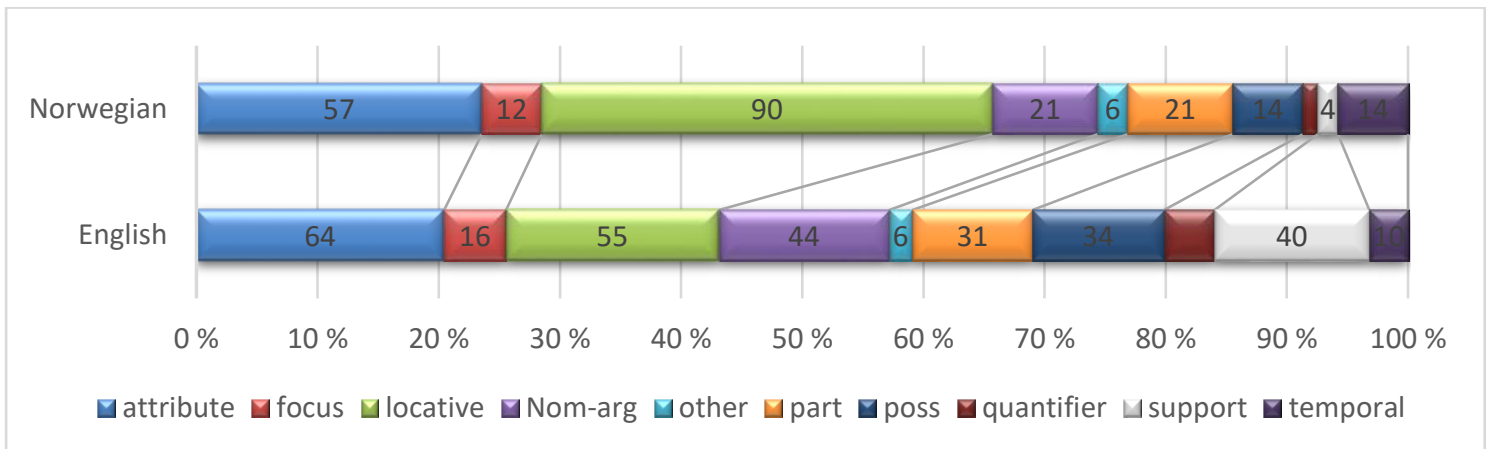

Figure 4. Meanings of postmodifying postnominal PPs in English (N=313) and Norwegian ( $\mathrm{N}=242)$.

In contrast, English has a greater proportion of postmodifiers with support meaning (13\% vs. $2 \%$ ) and possessive meaning (11\% vs. 6\%). Examples are given in (16) and (17). While the Norwegian translation has omitted the support noun in (16), the one in (17) follows the English original closely (see further Section 5.6).

(16) Then there was the matter of her job. (NG1)

Og så var det arbeidet hennes. (NG1T)

Lit: "And then there was the work hers"

(17) I came to realise that they were the voices of my spirit companions. (BO1)

... det var stemmene til mine følgesvenner i åndeverdenen. (BO1T)

Lit: "...it was the voices of my companions in the spirit world"

Figure 4 shows a slightly higher percentage of postmodifiers functioning as arguments in NPs with a nominalized head in English (14\%) than in Norwegian (8.7\%), although the frequency differences are perhaps not as great as might be expected on the basis of Behrens's (2014) comparison of nominalizations in English and Norwegian academic prose. Another possible difference between the languages is the type of arguments that occur as postmodifiers: in English equal proportions of the nominal arguments correspond to objects and adjuncts of clausal constructions, while in Norwegian a larger share correspond to adjuncts; see examples (18) and (19). The proportions of postmodifiers of nominalizations corresponding to subjects, as in (20), are similar. However, the numbers are low, so further study is needed to see if this is a trend.

(18) ... she had interrupted the shedding of her fourth husband to be present at her son's "first marriage". (AH1) (cp. She shed her fourth husband.)

...hun hadde utsatt å kvitte seg med sin fjerde mann for å være tilstede ved sønnens "første giftermål". (AH1T)

Lit: "she had postponed to get rid of her fourth husband..."

(19) Ingen flying etter jenter. (EFH1)

No running after girls. (EFH1T) (cp. You must not run after girls.)

(20) The presence of a man in the house subdued the women. (ST1) (cp. A man was present...)

Nå da en mann var kommet til stede, dempet kvinnene seg betraktelig. (ST1T)

Lit: "Now that a man had come to the place, the women calmed themselves considerably." 


\subsection{Translation of postnominal PPs}

The aligned translations of the concordance lines were analysed for their degree of congruence with their sources. The categories of correspondence are those outlined in Johansson (2007: 25), where 'congruent correspondence' means that the translated item belongs to the same formal category as that of its source, as in (19) above, while a non-congruent (or 'divergent') translation does not, as in (18) and (20) above. In the present study, congruent translations are those in which the postnominal PP has been translated by a PP with the same syntactic function. Zero correspondence means that the source item has been omitted in the translation. As in the above sections, PPs functioning as adverbials and postmodifiers are presented separately. The results for adverbials are shown in Figure 5. According to a Pearson's Chi-squared test, the two directions of translation differ only marginally: $\chi^{2}=5.84(2), p=0.05$.

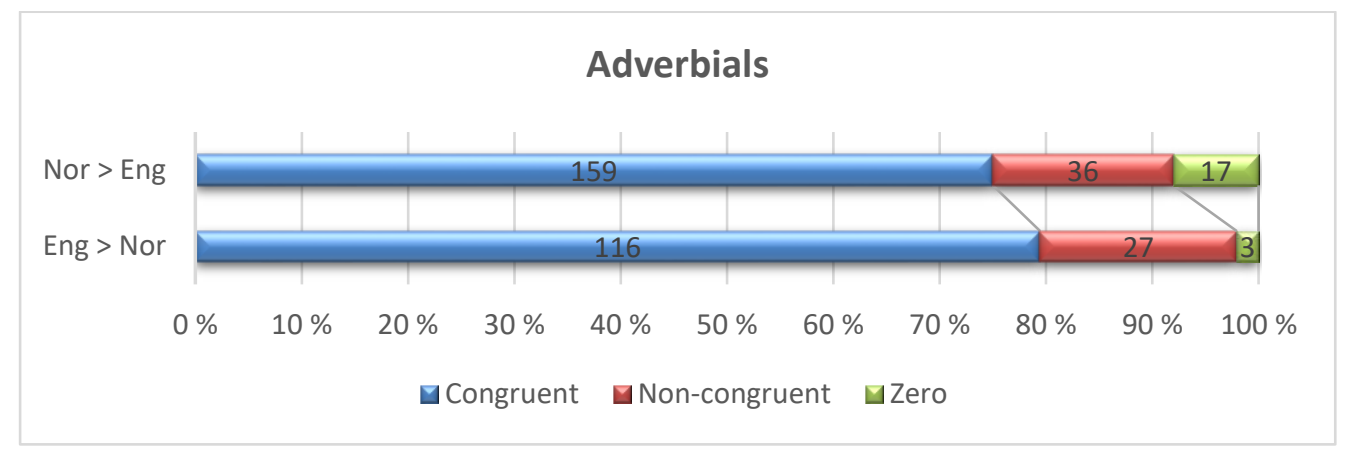

Figure 5. The translation of adverbial postnominal PPs.

The percentage of congruent translations of adverbial PPs is extremely high in both directions of translation: $74.5 \%$ in translations from Norwegian to English and 79.5\% in translations from English to Norwegian. This indicates that the resources as well as the preferences for forming adverbials in postnominal position are similar in the two languages. Although the difference between the two directions of translation is only borderline significant, the percentage of zero correspondence is noticeably higher in translations from Norwegian. The zero cases include some idiomatic expressions, such as se for seg ('see before one', 'imagine') as in example (21). In a few cases, the translation is so free that there is little trace of the syntax of the original, and sometimes the PP is omitted for no apparent reason, as in (22).

(21) Tora pleide å se Gunn for seg når hun lå alene i kammerset sitt om kvelden og ikke fikk sove. (HW1)

Lit: "Tora used to see Gunn before her when she lay alone..."

At night, when she was alone in her room and couldn't sleep, Tora would sometimes see Gunn. (HW1T)

(22) For ungdommen skal reise over sundet med ferja for å sjå på film... (EH1)

Lit: "For the young shall travel over the sound with the ferry for to see film"

The young people are crossing the sound [Ø] to go to the movies... (EH1T)

Non-congruent correspondences represent a variety of constructions, including differences in syntactic realization, as in (23) and (24), and in lexicalization, as in (25).

(23) Hvis vi retter det samme spørsmålet til en som fryser, er svaret varme. (JG1) Lit: "If we direct the same question at one who freezes, is the answer warmth." If we ask someone dying of cold, the answer is warmth. (JG1T)

(24) Aristotle remembered that such busts of Homer were common in Thessaly, Thrace, Macedonia, Attica, and Euboca in his lifetime. (JH1) 
Aristoteles husket at slike byster av Homer var alminnelige i Tessalia, Trakia, Makedonia, Attika og Euboia da han levde. (JH1T)

Lit: "... when he lived"

(25) Fikk fru Olsrud noe brev $i$ det siste? (EG1)

Lit: "Got Mrs Olsrud any letters in the last?"

Had she had any letters lately? (EG1T)

While the correspondences of adverbial PPs show a high degree of similarity between the languages and between the directions of translation, the analysis of postmodifying PPs indicate greater cross-linguistic differences. The degree of congruence is shown in Figure 6. According to a Pearson's Chi-squared test, the two directions of translation differ significantly: $\chi^{2}=23.66$ $(2), p<0.00001$.

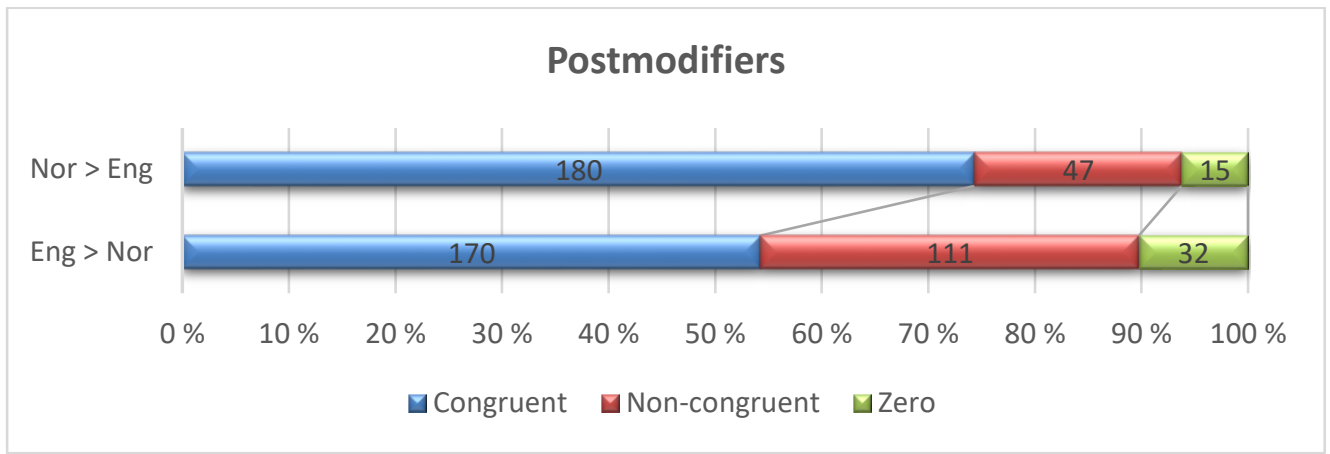

Figure 6. The translation of postmodifying postnominal PPs.

A striking feature of Figure 6 is the much higher proportion of congruent correspondences in translations from Norwegian into English than in the opposite direction. Hence, it appears to be easier to transfer the Norwegian pattern of postmodification into English than to translate English postmodifiers into Norwegian. The proportion of congruent English translations of Norwegian postmodifiers is $74.4 \%$, which is practically the same as in the case of congruent adverbials. Of English postmodifiers translated into Norwegian, by contrast, only $54.3 \%$ are congruent. Close examination of the English postmodifiers with non-congruent Norwegian correspondences reveals that the culprit is of: $71 \%$ of the non-congruent translations (79 out of 111) have of in the source. $O f$ is also responsible for $81 \%$ of the zero correspondences (26 out of 32), but only $48 \%$ (82 out of 170) of the congruent correspondences. ${ }^{11}$ There is no similarly discernible feature that can explain non-congruence in translation from Norwegian into English.

Prepositional phrases with of function predominantly as postmodifiers of nouns; only nine out of the 207 cases have other functions (respect adjunct, part of complex preposition, and part of multi-word verb). The most frequently occurring Norwegian preposition in congruent translations of of is its cognate av (46 occurrences, 22\%). Conversely, 37 out of 46 instances of $a v$ in postmodifying PPs (80\%) are translated by of. The most frequent meaning expressed in the congruent correspondences between $a v$ and of is the partitive one, shown in (26).

(26) Dermed smeller dørene igjen i dypet av skipet. (EFH1)

Lit: "Then slam the doors shut in the depth of the ship."

The doors slam shut in the bowels of the ship. (EFH1T)

11 This is in line with the findings of Hasselgård (2014: 64), where 'the N1 of the N2' had congruent correspondences in only $43.5 \%$ of Norwegian translations and $33 \%$ of Norwegian sources. 
Another typical meaning of $o f$-phrases is possession, i.e. the $o f$-genitive. Norwegian has a similar periphrastic genitive using the preposition $t i l$ (as an alternative to the $s$-genitive, like in English). However, the postmodifiers with possessive meaning tend to occur among divergent modifiers in both directions of translation: the prepositional genitives are translated congruently in less than a third of the cases. Non-congruent examples are given in (27) and (28).

(27) Broren til Tora sykler med blomsterpakker... (BV2)

Lit: "The brother of Tora cycles with flower-parcels"

Tora's brother delivers flowers by bicycle. (BV2T)

(28) David and Harriet were commended for their fertility, and jokes were made about the influences of their bedroom. (DL1)

David og Harriet ble rost for sin fruktbarhet, og man spøkte om soverommets innvirkning. (DL1T)

Lit: "... and one joked about the bedroom's influence."

The factors governing the choice between the $s$-genitive and the periphrastic genitive seem to differ between the languages. In Norwegian, the choice is to a large extent governed by formality (Holmes and Enger, 2018: 49). In both languages, the $s$-genitive is considered the more formal alternative, which is less likely to occur in speech. In English, an important additional factor is whether the possessor is human or non-human, although register also plays a role (Biber et al., 1999: 302). The periphrastic genitive is used with a human possessor in the Norwegian original of (26), while the English translator prefers the $s$-genitive. In (27), the possessor is non-human, but the style is rather formal, so English has the of-genitive and Norwegian the $s$-genitive. It may be noted that not all divergent correspondences of possessives are $s$-genitives; they may also be, for example, locative modifiers and relative clauses.

\section{Discussion and concluding remarks}

In Section 1, the following research questions were asked:

- What are the syntactic functions of PPs following a noun in Norwegian and English?

- What meanings do the PPs convey?

- $\quad$ Are there quantitative and qualitative differences between the languages as regards the functions and meanings of postnominal PPs?

- To what extent are translations congruent?

The analysis has shown that the same syntactic functions are found in the two languages, but with different frequencies. The 'noun + preposition' sequence represented postmodification of nouns and prenominal adjectives, clause-level adverbials, and components of complex prepositions and multi-word verbs. The greatest cross-linguistic difference concerns the overall proportions of adverbials and postmodifying PPs, where - as expected - English had a larger proportion of postmodifiers while Norwegian had a larger proportion of clause-level adverbials. The functions of PPs following nouns may thus support the claim (Nordrum, 2007; Behrens, 2014) that English is more nominal and Norwegian is more clausal. It may be noted that the higher frequencies of English postmodifiers resonate with the findings of MoreiraRodríguez (2006) and Mott (2013) who both conclude that the postmodifying function of PPs is more flexible in English than in Spanish. 
In terms of the meanings expressed, Norwegian postnominal PPs were locative more frequently than English ones in both adverbial and postmodifiying functions. Among the postmodifiers, English had more PPs modifying support nouns (Sinclair, 1991) as well as possessive constructions and modifiers of nominalizations. English also had larger proportions of adverbials with temporal and manner meanings. Other meanings were more similarly distributed.

The degree of congruence in translation differs across translation directions and syntactic functions. Adverbials are congruent in $75-80 \%$ of the cases in both directions of translation. Postmodifiers are congruent more often in translation from Norwegian to English (c. 74\%) than from English to Norwegian (c. 54\%). This indicates greater cross-linguistic differences in postmodifying than in adverbial PPs, and as a consequence, that postmodifying PPs are less straightforward for translators than adverbials are. Closer analysis showed that much of the difference regarding postmodifying PPs can be attributed to the special position of the highly frequent preposition of in combining "with preceding nouns to produce elaborations of the nominal group" (Sinclair, 1991: 83) and the great variety of meanings and relations that it can express. The fact that of lacks an equivalent in Norwegian can make Norwegian translators more inclined to change the structure. On the other hand, the translation of Norwegian postmodifiers into English does not involve any similarly difficult structure, which appears to make English translators more likely to keep the source structure.

Some of the findings of the present study must be regarded as tentative due to the limited scope of the investigation. The question of whether English is more nominal than Norwegian still remains to be resolved, even if the present study points in the same direction as e.g. Behrens (2014) and Nordrum (2007). However, future investigations need to cover more material and more registers in both languages. The finding that Norwegian PPs express locative meanings more often than English ones in both adverbial and postmodifying functions is interesting and should be followed up by studying PPs more generally without the restriction of a preceding noun, possibly also in comparison with other types of locative expression. The apparent language contrast in the conditions governing the periphrastic genitive vs. the $s$-genitive is another thread worth pursuing. Yet another is the detection of patterns in the sense of Hunston and Francis (2000) among those 'noun + PP' sequences that represent postmodification or complementation of nouns.

Finally, the chosen method of using a PoS-tag sequence as the basis of a cross-linguistic investigation proved to be productive in identifying cross-linguistic similarities and differences. As discussed in Section 3, the fact that different taggers were used for the two languages is a potential problem. In the present study, this problem was minimized by the fact that the structures that involved conflicting or controversial tags were relatively infrequent and hence will have had little impact on the main findings. It would, of course, have been reassuring for comparability if the two taggers had used the same tag set and the same PoS definitions, which might have been possible when the two languages are as closely related as Norwegian and English are (though see some misgivings voiced by Johansson (2007: 306)). However, the use of tag sequences rather than lexically defined searches also constitutes a kind of bottom-up procedure with the potential to retrieve instances and uses which might not have surfaced otherwise. Handled with care, tag sequences may indeed act as a window into cross-linguistic similarities and differences in lexicogrammar. 


\section{Corpus}

English-Norwegian Parallel Corpus (ENPC), fiction.

http://www.hf.uio.no/ilos/english/services/omc/, Accessed through Glossa at https://tekstlab.uio.no/glossa2/omc4 [Last accessed 2 June 2021].

\section{References}

Behrens, B. 2014. A Case Study of Linguistic Text Conventions in Comparable and Parallel texts: English and Norwegian. In Corpus-based Studies in Contrastive Linguistics, Oslo Studies in Language 6(1), S.O. Ebeling, A. Grønn, K.R. Hauge and D. Santos (eds), 143-160. http://www.journals.uio.no/osla [Last accessed 2 June 2021].

Biber, D., Johansson, S., Leech, G., Conrad, S. and Finegan, E. 1999. Longman Grammar of Spoken and Written English. London: Longman.

Brezina, V. 2018. Statistics in Corpus Linguistics: A Practical Guide. Cambridge: Cambridge University Press.

Egan, T. 2013. Between and through Revisited. In Corpus Linguistics and Variation in English: Focus on Non-native Englishes, M. Huber and J. Mukherjee (eds). VARIENG: Studies in Variation, $\begin{array}{lllll}\text { Contacts and } \text { Change } & \end{array}$ http://www.helsinki.fi/varieng/journal/volumes/13/egan/ [Last accessed 2 June 2021].

Elsness, J. 2014. Clausal Modifiers in Noun Phrases: A Comparison of English and Norwegian Based on the Oslo Multilingual Corpus. In Corpus-based Studies in Contrastive Linguistics, Oslo Studies in Language 6(1), S.O. Ebeling, A. Grønn, K.R. Hauge and D. Santos (eds), 91-118. http://www.journals.uio.no/osla [Last accessed 2 June 2021].

Faarlund, J.T., Vannebo, K.I. and Lie, S. 1997. Norsk Referansegrammatikk. Oslo: Universitetsforlaget.

Fang, A.C. 2000. A Lexicalist Approach towards the Automatic Determination for the Syntactic Functions of Prepositional phrases. Natural Language Engineering 6(2): 183-201.

Granger, S. and Bestgen, Y. 2014. The Use of Collocations by Intermediate vs.Advanced Non-native Writers: A Bigram-based Study. International Review of Applied Linguistics in Language Teaching, Volume 52(3): 229-252.

Granger, S. and Rayson, P. 1998. Automatic Profiling of Learner Texts. In Learner English on Computer, S. Granger (ed.), 119-131. London: Longman.

Hasselgård, H. 2010. Adjunct Adverbials in English. Cambridge: Cambridge University Press.

Hasselgård, H. 2014. Discourse-structuring Functions of Initial Adverbials in English and Norwegian News and Fiction. Languages in Contrast 14(1): 73-92 . doi: 10.1075/lic.14.1.05has

Hasselgård, H. 2016. The way of the world: The Colligational Framework 'the N1 of the N2' and its Norwegian Correspondences. Nordic Journal of English Studies 15(3): 55-79.

Hasselgård, H. 2019. The nature of the essays: The Colligational Framework 'the N of the N' in L1 and L2 Novice Academic English. In Corpus Approaches into World Englishes and Language Contrasts, H. Parviainen, M. Kaunisto and P. Pahta (eds). Studies in Variation, Contacts and Change in English, Vol. 20. https://varieng.helsinki.fi/series/ [Last accessed 2 June 2021].

Hasselgård, H. 2021. Time Adverbials in English and Norwegian News Discourse. In Time Languages, Languages in Time, A. Čermáková, T. Egan, H. Hasselgård and S. Rørvik (eds), 201-227. Amsterdam/Philadelphia: John Benjamins.

Holmes, P. and Enger, H.-O. 2018. Norwegian. A Comprehensive Grammar. London / New York: Routledge.

Huddleston, R. and Pullum, G.K. 2002. The Cambridge Grammar of the English Language. Cambridge: Cambridge University Press.

Hunston, S. and Francis, G. 2000. Pattern Grammar. A Corpus-driven Approach to the Lexical Grammar of English. Amsterdam/Philadelphia: John Benjamins. https://doi.org/10.1075/scl.4

Johansson, S. 2007. Seeing through Multilingual Corpora. On the Use of Corpora in Contrastive Studies. Amsterdam / Philadelphia: John Benjamins. https://doi.org/10.1075/scl.26 
Johannessen, J.B., Nygaard, L., Priestley, J. and Nøklestad, A. 2008. Glossa: a Multilingual, Multimodal, Configurable User Interface. In Proceedings of the 6th International Conference on Language Resources and Evaluation. 2008, 617-622. Available at http://urn.nb.no/URN:NBN:no-46163 [Last accessed June 2020].

Johannessen, J.B., Hagen, K., Lynum, A. and Nøklestad, A. 2012. OBT+stat. A Combined Rule-based and Statistical Tagger. In Exploring Newspaper Language. Corpus compilation and research based on the Norwegian Newspaper Corpus, G. Andersen (ed.), 51-65. Amsterdam/Philadelphia: John Benjamins. https://doi.org/10.1075/scl.49.03joh

Leech, G.. 2011. Principles and Applications of Corpus Linguistics. In Perspectives on Corpus Linguistics, V. Viana, S. Zyngier and G. Barnbrook (eds), 155-170. Amsterdam/Philadelphia: John Benjamins. https://doi.org/10.1075/scl.48.10lee

Moreira-Rodríguez, A. 2006. 'The book on the table', 'The man in the moon': Post-modification of Nouns by Preposition + Noun in English and Castilian. Bulletin of Spanish Studies 83(1): 53-72. DOI: $10.1080 / 1475382062000346045$

Mott, B. 2013. Postmodifying Prepositional Phrases in English and Spanish (with Special Reference to Locative Postmodifiers). $\quad$ Transfer 8(1-2): 153-170. DOI: https://doi.org/10.1344/transfer.2013.8.153-160.

Nordrum, L. 2007. English Lexical Nominalizations in a Norwegian-Swedish Contrastive Perspective. $\mathrm{PhD}$ thesis, University of Göteborg. https://gupea.ub.gu.se/bitstream/2077/17181/5/gupea_2077_17181_5.pdf [Last accessed June 2020].

Renouf, A. and Sinclair, J. 1991. Collocational Frameworks in English. In English Corpus Linguistics: Studies in Honour of Jan Svartvik, K. Aijmer and B. Altenberg (eds), 128-144. London: Longman.

Sinclair, J. 1991. Corpus, Concordance, Collocation. Oxford: Oxford University Press.

Wilhelmsen, A. 2019. Pretty complete or completely pretty? Investigating Degree Modifiers in English and Norwegian Original and Translated Text. MA thesis. Faculté de philosophie, arts et lettres, Université catholique de Louvain, 2019. http://hdl.handle.net/2078.1/thesis:18894 [Last accessed June 2020].

Author's address

Hilde Hasselgård

Department of Literature, Area Studies and European Languages

University of Oslo

P.O. box 1003, Blindern

NO-0315 Oslo

Norway

hilde.hasselgard@ilos.uio.no 
Hilde Hasselgård 